\title{
Piggery pond sludge as a nitrogen source for crops. 1. Mineral N supply estimated from laboratory incubations and field application of stockpiled and wet sludge
}

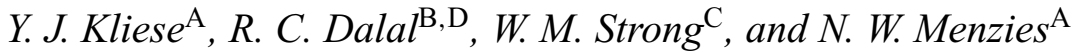 \\ ${ }^{\text {A }}$ School of Land and Food Sciences, University of Queensland, St Lucia, Qld 4072, Australia. \\ ${ }^{B}$ Department of Natural Resources and Mines, 80 Meiers Road, Indooroopilly, Qld 4068, Australia. \\ ${ }^{\mathrm{C}}$ Department of Primary Industries and Fisheries, Toowoomba, Qld 4350, Australia. \\ ${ }^{\mathrm{D}}$ Corresponding author. Email: Ram.Dalal@nrm.qld.gov.au
}

\begin{abstract}
Piggery pond sludge (PPS) was applied, as-collected (Wet PPS) and following stockpiling for 12 months (Stockpiled PPS), to a sandy Sodosol and clay Vertosol at sites on the Darling Downs of Queensland. Laboratory measures of $\mathrm{N}$ availability were carried out on unamended and PPS-amended soils to investigate their value in estimating supplementary $\mathrm{N}$ needs of crops in Australia's northern grains region. Cumulative net $\mathrm{N}$ mineralised from the long-term ( 30 weeks) leached aerobic incubation was described by a first-order single exponential model. The mineralisation rate constant $(0.057 /$ week $)$ was not significantly different between Control and PPS treatments or across soil types, when the amounts of initial mineral $\mathrm{N}$ applied in PPS treatments were excluded. Potentially mineralisable $\mathrm{N}\left(\mathrm{N}_{\mathrm{o}}\right)$ was significantly increased by the application of Wet PPS, and increased with increasing rate of application. Application of Wet PPS significantly increased the total amount of inorganic N leached compared with the Control treatments. Mineral N applied in Wet PPS contributed as much to the total mineral N status of the soil as did that which mineralised over time from organic $\mathrm{N}$. Rates of $\mathrm{CO}_{2}$ evolution during 30 weeks of aerobic leached incubation indicated that the Stockpiled PPS was more stabilised (19-28\% of applied organic C mineralised) than the Wet PPS (35-58\% of applied organic C mineralised), due to higher lignin content in the former. Net nitrate-N produced following 12 weeks of aerobic non-leached incubation was highly correlated with net nitrate$\mathrm{N}$ leached during 12 weeks of aerobic incubation $\left(R^{2}=0.96\right)$, although it was $<60 \%$ of the latter in both sandy and clayey soils. Anaerobically mineralisable N determined by waterlogged incubation of laboratory PPS-amended soil samples increased with increasing application rate of Wet PPS. Anaerobically mineralisable $\mathrm{N}$ from field-moist soil was well correlated with net $\mathrm{N}$ mineralised during 30 weeks of aerobic leached incubation $\left(R^{2}=0.90\right.$ sandy soil; $R^{2}=0.93$ clay soil). In the clay soil, the amount of mineral $\mathrm{N}$ produced from all the laboratory incubations was significantly correlated with field-measured nitrate- $\mathrm{N}$ in the soil profile $(0-1.5 \mathrm{~m}$ depth) after 9 months of weed-free fallow following PPS application. In contrast, only anaerobic mineralisable $\mathrm{N}$ was significantly correlated with field nitrate-N in the sandy soil. Anaerobic incubation would, therefore, be suitable as a rapid practical test to estimate potentially mineralisable $\mathrm{N}$ following applications of different PPS materials in the field.
\end{abstract}

Additional keywords: piggery manure, nitrogen mineralisation potentials, aerobic mineralisable $\mathrm{N}$, anaerobic mineralisable $\mathrm{N}$, ammonium- $\mathrm{N}$, nitrate- $\mathrm{N}$.

\begin{abstract}
Introduction
Appropriate disposal of waste is a significant issue for the pig industry in Australia and worldwide due to increasing concerns of regulatory authorities to avoid environmental pollution (Kliese 2002). Commonly, piggery waste is collected in large earthen ponds, which eventually become overloaded with solids as liquid effluent is usually recycled through irrigation. Periodic removal of pond sediment or sludge is required to maintain pond performance. Piggery pond sludge (PPS) may be removed as a suspension by a
\end{abstract}

vacuum tanker and applied to land directly (wet), or allowed to dry in stockpiles and then applied to land using a solids spreader (Kliese 2002).

Piggery pond sludge applied to cropping land is a potential source of supplementary nutrients for crop production. In northern Australia, nitrogen $(\mathrm{N})$ contained in PPS may provide some of the supplementary $\mathrm{N}$ that is now required for most broadacre field crops. Thus, knowledge of the kinetics of release of plant-available $\mathrm{N}$ is essential if PPS is to be used as a valued resource for crop production. 
The kinetics of release of mineral $\mathrm{N}$ from animal wastes is also of importance for its land application to avoid nitrate $\left(\mathrm{NO}_{3}\right)$ pollution of surface and groundwater when applied in excess (Rate and Cameron 1992; Bernal and Roig 1993; Cameron et al. 1995; Carey et al. 1997; Estavillo et al. 1997). The kinetics of release of mineral $\mathrm{N}$ from PPS is controlled by soil microorganisms and environmental parameters that affect soil biological activity. Soil moisture, temperature, texture, $\mathrm{pH}$, and PPS composition will influence the rate and extent of mineralisation (Zebarth et al. 1996; Zaman et al. 1998). Studies on $\mathrm{N}$ mineralisation from livestock waste applications, both in the laboratory and in the field, have revealed large variations in mineralisable $\mathrm{N}$, making it difficult to develop guidelines for its application as a supplementary source of N (Castellanos and Pratt 1981; Serna and Pomares 1991; Paul and Beauchamp 1994; Gilmour et al. 2003; Yang et al. 2004).

Kinetic studies on $\mathrm{N}$ transformations in soils amended with pond sludge from intensive livestock facilities are few (Cameron et al. 1996; Zaman et al. 1998), and have been almost exclusively confined to temperate environments (Westerman et al. 1987; Ndayegamiye and Côté 1989; Rees et al. 1993; Paul and Beauchamp 1995; Cameron et al. 1996; Carey et al. 1997; Rochette et al. 2000). The objectives of our study were to: (1) compare the patterns of $\mathrm{N}$ release from wet or stockpiled PPS; (2) improve the prediction of $\mathrm{N}$ availability in the field for crop production following application of PPS to 2 contrasting soils in Australia's subtropical northern cereal region; and (3) evaluate PPS application in terms of equivalent rates of a synthetic $\mathrm{N}$ fertiliser (urea).

In this paper we report results that address objectives (1) and (2) above, while objective (3) is addressed in the following paper. We evaluated patterns of $\mathrm{N}$ release from PPS applied to a sandy soil and a clay soil under controlled moisture and temperature conditions in the laboratory. Mineralisation of $\mathrm{N}$ was assessed using long-term (30 weeks) aerobic leached incubation (Stanford and Smith 1972), short-term (12 weeks) aerobic non-leached incubation (Hart et al. 1994), and anaerobic (waterlogged) incubation for 7 days at $40^{\circ} \mathrm{C}$ (Keeney 1982). These laboratory assessments were then compared with field measurements of $\mathrm{NO}_{3}-\mathrm{N}$ accumulated in the soil profile $(0-1.5 \mathrm{~m})$ during a 12-month weed-free fallow period after PPS applications.

\section{Materials and methods}

\section{Soils}

Two soils of contrasting texture were used for the field trials and the laboratory incubation experiments. These were Millmerran sandy soil (Sodosol; Isbell 1996; Typic Natrustalf; USDA 1975), and Formartin clay soil (Vertosol; Isbell 1996; Udic Haplustert; USDA 1975). The Millmerran site was coarse-textured ( $8 \%$ clay) and had a neutral surface $\mathrm{pH}$ (6.7 at $0-0.1 \mathrm{~m}$ depth), whereas the Formartin site was finetextured (56\% clay) and had an alkaline surface $\mathrm{pH}(8.1$ at $0-0.1 \mathrm{~m}$ depth) (Table 1). Organic $\mathrm{C}$ and total $\mathrm{N}$ in the $0-0.1 \mathrm{~m}$ layers were
Table 1. Characteristics of the two soils of the Darling Downs of Queensland to which stockpiled and wet piggery pond sludge was applied

\begin{tabular}{lccccc}
\hline Soil type & $\mathrm{pH}$ & $\begin{array}{c}\text { Sand } \\
(\%)\end{array}$ & $\begin{array}{c}\text { Silt } \\
(\%)\end{array}$ & $\begin{array}{c}\text { Clay } \\
(\%)\end{array}$ & $\begin{array}{c}\text { CEC } \\
(\mathrm{cmol} / \mathrm{kg})\end{array}$ \\
\hline $\begin{array}{l}\text { Millmerran sandy loam } \\
\quad \text { (Sodosol) }\end{array}$ & 6.7 & 86 & 6 & 8 & 7.0 \\
$\begin{array}{l}\text { Formartin clay } \\
\text { (Vertosol) }\end{array}$ & 8.1 & 32 & 12 & 56 & 51.3 \\
\hline
\end{tabular}

$0.54 \%$ and $0.04 \%$, respectively, in the sandy soil and $1 \%$ and $0.08 \%$, respectively, in the clay soil.

The Millmerran field trial site was located on a soil originally under bull oak (Casuarina leuhmannii) and iron bark (Eucalyptus sideroxylon) vegetation at Millmerran $\left(27^{\circ} 88^{\prime} \mathrm{S}, 151^{\circ} 21^{\prime} \mathrm{E}\right)$, Qld, Australia. The climate of the region is subtropical, with mean annual rainfall of $666 \mathrm{~mm}$ and mean annual temperature of $19.9^{\circ} \mathrm{C}$. Approximately $34 \%$ of the annual rainfall is received in the winter months (April-September inclusive) (Clewett et al. 1999). The site was cleared approximately 50 years ago and was cropped annually for 35 years, mainly to barley (Hordeum vulgare). Since 1985 the area was sown infrequently with oats (Avena sativa). The site received an application of poultry manure in 1993 at approximately $2.4 \mathrm{t} / \mathrm{ha}$. Sheep have grazed the site regularly. The soil is a marginal agricultural soil with the main limitations to agricultural production being low $\mathrm{N}$ and $\mathrm{P}$, low water-holding capacity, and a hardsetting surface.

The Formartin field trial site was located on a soil originally under grassland vegetation at Formartin $\left(27^{\circ} 20^{\prime} \mathrm{S}, 157^{\circ} 23^{\prime} \mathrm{E}\right)$, Qld, Australia. The climate of the region is subtropical, with mean annual rainfall of $644 \mathrm{~mm}$ and mean annual temperature of $19.1^{\circ} \mathrm{C}$. Approximately $33 \%$ of the annual rainfall is received in the winter months (AprilSeptember inclusive) (Clewett et al. 1999). The site was cleared between 1940 and 1942 and was cropped annually for approximately 60 years, mainly to cereal crops. The soil has few limitations with respect to agricultural capability, but is responsive to $\mathrm{N}$ and $\mathrm{P}$ applications. The site had never previously received manure applications nor had it been grazed by livestock during the last 50 years.

For site characterisation, soil samples were collected from each field trial site using a hydraulically operated core sampler with a 50 -mm-diameter cutting edge. Six cores were sectioned into 7 depth intervals, $0-0.1,0.1-0.2,0.2-0.3,0.3-0.6,0.6-0.9,0.9-1.2$, and $1.2-1.5 \mathrm{~m}$, and the respective depth intervals were combined from 2 cores to obtain 3 samples for each depth interval. The soil samples were sealed in polyethylene bags in the field and stored at $4{ }^{\circ} \mathrm{C}$ until further processing. Samples were weighed, then placed in a forceddraught dehydrator and dried at $40^{\circ} \mathrm{C}$ for approximately 7 days. Following air-drying, the soil was ground to pass a $<2-\mathrm{mm}$ sieve. After mixing thoroughly and collecting a subsample, the samples were stored in sealed plastic containers at room temperature until further analysis. A soil subsample was further ground to pass a $0.25-\mathrm{mm}$ sieve for organic $\mathrm{C}$ and total $\mathrm{N}$ analysis. Six additional samples were obtained for incubation studies from the $0-10 \mathrm{~cm}$ layer, sieved $(<4 \mathrm{~mm})$, and stored in field-moist conditions at $4{ }^{\circ} \mathrm{C}$ until further analysis.

Piggery pond sludge (PPS)

Wet PPS was extracted from a storage pond located on a piggery farm at Millmerran, using a vacuum tanker, and 3 samples $(3 \times 20$-L drums) were collected from an outlet on the tanker and stored in air-tight containers at $4{ }^{\circ} \mathrm{C}$ until further processing. Samples were homogenised and subsampled $(1 \mathrm{~L})$ for analysis. Stockpiled PPS was collected from a piggery located at Westbrook, Qld, Australia, after it had been 
stockpiled for 12 months. It was dried further after collection on a concrete pad, turned frequently, and then sieved to $<10 \mathrm{~mm}$. Three samples of Stockpiled PPS $(3 \times 5 \mathrm{~kg})$ were collected, homogenized, and subsampled $(500 \mathrm{~g})$. Samples of Wet PPS and Stockpiled PPS were each halved. One half was stored at $4{ }^{\circ} \mathrm{C}$ in its moist state for analysis of PPS composition in an as-collected state; the other half was weighed into a forced-draught dehydrator and dried at $40^{\circ} \mathrm{C}$ for approximately 7 days. After air-drying, samples were reweighed in order to determine the air-dry moisture content. Stockpiled PPS was ground finely to $<0.2 \mathrm{~mm}$ using a Glen Creston micro-hammermill to enable uniform representative small volumes to be analysed. A subsample was dried at $105^{\circ} \mathrm{C}$ for $48 \mathrm{~h}$ to determine the oven-dry moisture content of the PPS air-dried at $40^{\circ} \mathrm{C}$. Properties of the Wet PPS and the Stockpiled PPS are expressed on an oven-dry weight basis and presented in Table 2. $\mathrm{NH}_{4}-\mathrm{N}$ and $\mathrm{NO}_{3}-\mathrm{N}$ contents of both PPS were determined from samples 'as collected', although air-drying of Stockpiled PPS at $40^{\circ} \mathrm{C}$ had little effect on mineral $\mathrm{N}$ content.

\section{Design of laboratory studies}

Laboratory incubations simulated the applications of PPS at the 2 field sites. Quantities of each sludge were mixed with each soil to establish a mixture of soil and sludge equivalent to those for each field application rate. Four replications of each sludge rate were used for each laboratory incubation experiment (aerobic leached, aerobic nonleached, and waterlogged mineralisation).

\section{Aerobic leached incubation}

The potentially mineralisable $\mathrm{N}$ (mineralisation potentials) in soil amended with PPS was measured by the aerobic leached incubation procedure proposed by Stanford and Smith (1972), with improvements developed by Bundy and Meisinger (1994). The method was modified in order to utilise a $75-\mathrm{mL}$ syringe $(2.5-\mathrm{cm}$ diam. $\times 13.5-\mathrm{cm}$ length) as a combined filtration-incubation container. A glass-fibre filter (extra thick, $1 \mu \mathrm{m}, 25 \mathrm{~mm}$ diam., no. 66075, Gelman Sciences Inc.), 20- $\mu \mathrm{m}$ frit for 75-mL syringe (no. AGS51FR75, Activon), untreated glass wool (Alltech), and acid-washed sand (AJAX) were used for filtration in the clay soil treatments. The glass-fibre filter and $20-\mu \mathrm{m}$ frit were omitted for the sandy soil treatments due to clogging by fine clay particles during preliminary tests. Glass wool and acid washed sand were placed on top of the frit and glass-fibre filter to prevent soil particles clogging the filters and to decrease channelling of the leachate.

Table 2. Composition of piggery pond sludge (PPS) applied to two grain-producing soils of subtropical northern Australia expressed on an oven-dry weight basis

\begin{tabular}{|c|c|c|}
\hline Property (air-dried at $40^{\circ} \mathrm{C}$ ) & Wet PPS & Stockpiled PPS \\
\hline Total solids (\%) & 8.6 & 85.9 \\
\hline $\mathrm{pH}$ & 7.5 & 6.6 \\
\hline $\mathrm{EC}(\mathrm{dS} / \mathrm{m})$ & 5.4 & 1.9 \\
\hline Lignin $(\%)$ & 18.8 & 12.5 \\
\hline Acid digestible fibre (\%) & 28.2 & 22.8 \\
\hline Cellulose $(\%)$ & 9.3 & 10.3 \\
\hline Total C (\%) & 25.1 & 6.0 \\
\hline Total N (\%) & $4.6^{\mathrm{A}}$ & 0.77 \\
\hline $\mathrm{C} / \mathrm{N}$ ratio & 5.5 & 7.8 \\
\hline $\mathrm{C} /$ organic $\mathrm{N}$ ratio & 8.8 & 9.2 \\
\hline Lignin/organic $\mathrm{N}$ ratio & 5.9 & 19.2 \\
\hline $\mathrm{NH}_{4}-\mathrm{N}(\mathrm{mg} / \mathrm{kg})$ & 189 & 58 \\
\hline $\mathrm{NO}_{3}-\mathrm{N}(\mathrm{mg} / \mathrm{kg})$ & 0 & 892 \\
\hline Mineral N (mg/kg) & 189 & 950 \\
\hline
\end{tabular}

\footnotetext{
${ }^{\mathrm{A}}$ Wet PPS acidified with $\mathrm{HCl}$ and dried at $105^{\circ} \mathrm{C}$ overnight.
}

Field-moist soil was used in order to avoid artefacts from air-drying and to minimise reduction of the nitrifier population. Wet PPS and Stockpiled PPS were applied to soil in their as-collected state (i.e. they were not dried and ground prior to application). The PPS was applied at the intended field trial application rates of $6 \mathrm{t} / \mathrm{ha}$ (D1) and $18 \mathrm{t} / \mathrm{ha}$ (D2) of Stockpiled PPS and 17.5 t/ha (W1) and 52.5 t/ha (W2) of Wet PPS, therefore the treatments were comparable across soil types. The PPS rates were calculated on a mass of soil basis taking into account the bulk density of the field soil. Untreated soils were also included as control (C). The required amount of PPS was added to the field-moist soil and thoroughly mixed prior to the addition of acid-washed sand. Acid-washed sand was added in order to maintain favourable water transmission and aeration for the period of the incubation. The sandy soil was mixed at a $1: 1$ ratio ( $30 \mathrm{~g}$ soil $: 30 \mathrm{~g}$ quartz sand), whereas twice the amount of quartz sand ( $20 \mathrm{~g}$ soil : $40 \mathrm{~g}$ quartz sand) was incorporated for the clay soil to compensate for its high clay content (Campbell et al. 1981; Dalal and Mayer 1987). Following thorough mixing of the soilPPS-sand mixture, deionised water was added to bring the soil to field capacity ( $40 \%$ and $12.5 \%$ gravimetric water contents for the clay soil and the sandy soil). The soil-PPS-sand mixture was then transferred into the syringe, and glass wool and a glass-fibre filter were placed on top of the soil in order to minimise soil dispersion during leaching. Four blanks consisting of filters, glass wool, and acid-washed sand were included to account for trace amounts of $\mathrm{N}$ and $\mathrm{C}$ derived from the filtration materials.

Net $\mathrm{N}$ mineralisation of amended and unamended soil was monitored over 30 weeks of incubation. Soil-PPS-sand mixtures were incubated in a constant temperature room at $21^{\circ} \mathrm{C} \pm 1^{\circ} \mathrm{C}$. This temperature was similar to the mean annual temperature at the 2 field trial sites. The soil columns were leached immediately prior to the initial incubation, Time 0 , and again after 1, 2, 4, 8, 12, 16, 22, and 30 weeks of incubation. An initial leaching was necessary to exclude inorganic $\mathrm{N}$ applied in PPS amendments and accumulated by soil prior to the commencement of the incubation study.

Syringes containing filters and soil-PPS-sand mixtures were weighed and placed on a vacuum manifold capable of accommodating 24 syringes per leaching. A vacuum regulator and manometer were used to control and monitor the vacuum level. Leachates were collected under a vacuum of $10 \mathrm{kPa}$ for the clay soil treatments, which leached slowly, and $3 \mathrm{kPa}$ for the sandy soil treatments, which leached rapidly, so that essentially similar leaching rates were achieved in both soils. Mineralised $\mathrm{N}$ in the soil columns was leached with $100 \mathrm{~mL}$ of $0.01 \mathrm{M}$ calcium chloride $\left(\mathrm{CaCl}_{2}\right)$ solution followed by $25 \mathrm{~mL}$ of minus- $\mathrm{N}$ nutrient solution containing $0.002 \mathrm{M} \mathrm{CaSO}_{4}$, $0.002 \mathrm{M} \mathrm{MgSO}_{4}, 0.005 \mathrm{M} \mathrm{Ca}\left(\mathrm{H}_{2} \mathrm{PO}_{4}\right)_{2}$, and $0.0025 \mathrm{M} \mathrm{K}_{2} \mathrm{SO}_{4}$ at the rate of $150 \mathrm{~mL} / \mathrm{h}$. A constant head was maintained on the soil during leaching.

Following leaching, a vacuum of $25 \mathrm{kPa}$ was applied to the clay soil and $10 \mathrm{kPa}$ to the sandy soil for approximately $15 \mathrm{~min}$ to remove excess moisture and to provide a uniform moisture content in the soil-PPS-sand mixture for the subsequent incubation period. The syringe was disconnected from the vacuum manifold, weighed, and the bottom sealed with Parafilm and the top of the syringe left unsealed to allow air exchange during incubation. Syringes were weighed prior to and after leaching to enable water loss between leaching events and leachate volume to be determined in order to calculate $\mathrm{N}$ leached on a $\mathrm{mg} / \mathrm{kg}$ oven-dry soil basis. Water loss during incubation intervals was minimal. Leachates from the sandy soil treatments were cloudy as a result of the frit and glass-fibre filter being omitted. Therefore, the leachates were filtered through pre-rinsed Whatman no. 40 filter papers. All solutions were stored at $4^{\circ} \mathrm{C}$ prior to analysis. Percentage of organic N [mineralised from the PPS treatments was calculated as follows: 100 mineralised $\mathrm{N}$ at 30 weeks in the PPS treatment - (mineralised $\mathrm{N}$ at 30 weeks in the control treatment + initial 
mineral $\mathrm{N}$ in PPS $+\mathrm{NO}_{3}-\mathrm{N}$ produced in the first 2 weeks due to soil disturbance)]/initial organic $\mathrm{N}$ in PPS.

Carbon mineralisation was determined simultaneously with $\mathrm{N}$ mineralisation by enclosing the incubation syringe inside a $750-\mathrm{mL}$ glass jar and capturing the $\mathrm{CO}_{2}$ evolved in an alkali trap (Anderson 1982). The alkali trap was a $10-\mathrm{mL}$ volumetric vial containing $1 \mathrm{~mL}$ of $1 \mathrm{~m} \mathrm{NaOH}$. Approximately $40 \mathrm{~mL}$ of water was placed at the base of the glass jar to maintain humidity and minimise soil water loss during incubation. Blanks, consisting of glass jars containing water and alkali traps, were included to account for background $\mathrm{CO}_{2}$. Blank values were consistently low.

\section{Aerobic non-leached incubation}

Short-term laboratory incubations, such as the aerobic non-leached (12 weeks) and anaerobic incubation (7 days), are considered to be more practical than aerobic leached incubations that take 30 weeks as routine laboratory incubations to determine $\mathrm{N}$ availability following amendment of soil with PPS. The soil and sludge mixtures used in the aerobic leached incubation experiment mentioned above were similar to those used for aerobic non-leached incubations.

Mineralisable $\mathrm{N}$ in soil amended with PPS was measured by the aerobic non-leached procedure described by Hart et al. (1994). Experimental treatments were obtained by applying Wet PPS and Stockpiled PPS at the required rate to field-moist soil (equivalent to $200 \mathrm{~g}$ of oven-dry soil). Soil-PPS mixtures were thoroughly mixed and placed into containers $(8-\mathrm{cm}$ diam. $\times 16-\mathrm{cm}$ height $)$ and the moisture content was adjusted to field capacity by the addition of deionised water. Treatments were incubated aerobically for 12 weeks in the dark in a controlled-temperature growth cabinet maintained at $20 \pm 0.6^{\circ} \mathrm{C}$ and at $94 \pm 2 \%$ humidity. Containers were covered with perforated plastic wrap, which allowed gas exchange and minimised water loss. Water loss was monitored every $2-3$ days by weighing containers, and the moisture content was adjusted by returning the container to its original weight with deionised water.

Concentrations of mineral $\mathrm{N}$ were determined following $0,0.5,1,2$, 4,8 , and 12 weeks of incubation. At each sampling time, 4 replications of each Control and soil-PPS treatment were randomly selected for analysis and analysed using $2 \mathrm{M} \mathrm{KCl}$ as an extractant ( $1: 4$ soil : extractant), and filtered through pre-rinsed Whatman no. 40 filter papers. All extracts were stored at $4{ }^{\circ} \mathrm{C}$ prior to analysis for mineral $\mathrm{N}$.

\section{Anaerobic (waterlogged) incubation}

Mineralisable $\mathrm{N}$ in soil amended with PPS was measured by incubation under waterlogged (anaerobic) conditions for 7 days at $40^{\circ} \mathrm{C}$ (Keeney 1982). Control and PPS-amended field-moist soil equivalent to $5 \mathrm{~g}$ of oven-dry soil was extracted immediately (Time 0 ) and an equivalent to $5 \mathrm{~g}$ of oven-dry soil was anaerobically incubated for 7 days at $40^{\circ} \mathrm{C}$ in $12.5 \mathrm{~mL}$ of water. To assess the effect of air-drying soil prior to waterlogged incubation, the remaining Control and PPSamended field-moist soil, $10 \mathrm{~g}$ of oven-dry soil, was air-dried at $40^{\circ} \mathrm{C}$ for 7 days.

Methodology presented by Bundy and Meisinger (1994) was modified and ammonium- $\mathrm{N}\left(\mathrm{NH}_{4}-\mathrm{N}\right)$ was extracted by the addition of $37.5 \mathrm{~mL}$ of $2.67 \mathrm{M} \mathrm{KCl}$ to the test tube containing the waterlogged soil mixture and shaking for $1 \mathrm{~h}$. Extracts were filtered through prerinsed Whatman no. 40 filter papers and stored at $4{ }^{\circ} \mathrm{C}$ prior to analysis for $\mathrm{NH}_{4}$.

\section{Soil nitrate accumulation in field experiments}

Field experiments consisted of 5 PPS treatments: 2 rates of Wet PPS (17.5 and $52.5 \mathrm{t} / \mathrm{ha}, \mathrm{W} 1$ and $\mathrm{W} 2$, respectively), 2 rates of Stockpiled PPS ( 6 and $18 \mathrm{t} /$ ha, D1 and D2, respectively), and an unamended control (C). Four replicates of each treatment were arranged in a randomised block design. The plot size at both sites was 9 by $25 \mathrm{~m}$, and the plots were split longitudinally ( 4.5 by $25 \mathrm{~m}$ each) for summer and winter crops. Plot width was determined by both the wet sludge spread width of $8.5 \mathrm{~m}$ and the planter/harvester width of 4 rows of $2.25 \mathrm{~m}$ each. Plot locations within the randomised block design remained the same throughout the experiment.

Stockpiled PPS was applied by hand on the 17 and 18 December 1997 at Formartin and Millmerran, respectively. Wet PPS was collected from a non-agitated lagoon, using a vacuum tanker, and was applied on 19 December 1997. The vacuum tanker used a splash plate for spreading the Wet PPS. The Wet PPS was incorporated to approximately $0.15-\mathrm{m}$ soil depth within $30 \mathrm{~min}$ of application at each site, with offset discs in order to minimise $\mathrm{NH}_{3}$ volatilisation. Stockpiled PPS was incorporated at the same time as the Wet PPS. Subsamples of both PPS were taken for laboratory studies and chemical analysis. Weeds were controlled on the trial sites by manual chipping along with the selective use of herbicides. Roundup (glyphosate) was used for total control of weeds in fallow areas.

After application of PPS, plots were sampled for $\mathrm{NO}_{3}-\mathrm{N}$ in January, February, March, and September 1998 during the fallow period. Two cores were collected per plot by a hydraulically operated core sampler with a 50-mm-diameter cutting edge. Cores were sectioned into 7 depth intervals, $0-0.1,0.1-0.2,0.2-0.3,0.3-0.6,0.6-0.9,0.9-1.2$, and $1.2-1.5 \mathrm{~m}$, and the respective depth intervals from the 2 cores were combined. The soil samples were sealed in polyethylene bags in the field and stored at $4{ }^{\circ} \mathrm{C}$ until further processing. Samples were weighed, then placed in a forced-draught dehydrator and dried at $40^{\circ} \mathrm{C}$ for approximately seven days. Following air-drying, samples were ground $(<2 \mathrm{~mm})$ for analysis. Nitrate was extracted with $2 \mathrm{M} \mathrm{KCl}$ at a soil : extractant ratio of $1: 10(10 \mathrm{~g}$ soil : $100 \mathrm{~mL} \mathrm{KCl})$ (Bremner 1965). Extracts were filtered through pre-rinsed Whatman no. 40 filter papers, and stored at $4{ }^{\circ} \mathrm{C}$ until analysed for $\mathrm{NO}_{3}$.

\section{Analytical procedures}

Particle size distribution was measured by dispersing soil $(<2 \mathrm{~mm})$ with a Cullex cation exchange resin (Edwards and Bremner 1965). Clay $(<0.002 \mathrm{~mm})$ and silt $(0.002-0.02 \mathrm{~mm})$ were determined by a pipette and sedimentation procedure (Day 1965). Sand $(0.02-2.0 \mathrm{~mm})$ was calculated by difference. Soil $\mathrm{pH}$ was measured in the supernatant liquid of a $1: 5$ (soil: deionised water) suspension (Rayment and Higginson 1992). Cation exchange capacity was measured using alcoholic $1 \mathrm{~m}$ ammonium chloride at $\mathrm{pH} 8.5$ (Rayment and Higginson 1992). Finely ground $(<0.25 \mathrm{~mm})$ soil samples were analysed for organic $\mathrm{C}$ by the dichromate oxidation method (Walkley and Black 1934), followed by measurement of chromium (Cr III) produced relative to sucrose standards (Sims and Haby 1971). Soil total $\mathrm{N}$ was determined using a semimicro Kjeldahl digestion with colourimetric $\mathrm{N}$ quantification using the indophenol blue method (Rayment and Higginson 1992). Ammonium $\left(\mathrm{NH}_{4}\right)$ concentration in extracts was determined by an automated procedure using a modified Berthelot indophenol reaction with alkaline $\mathrm{Na}$ salicylate/nitroprusside/isocyanurate (Crooke and Simpson 1971). Nitrate- $\mathrm{N}$ in $\mathrm{KCl}$ extracts was determined by an automated hydrazine reaction procedure for the Griess-Ilosvay reaction for $\mathrm{NO}_{2}$ (Best 1976). Soil profile $\mathrm{NO}_{3}-\mathrm{N}$ content was expressed on an oven-dry weight basis $(\mathrm{kg} / \mathrm{ha})$ from soil moisture content and BD for each layer. Sorbed $\mathrm{CO}_{2}$ in the soil respiration experiment was determined by adding $60 \mathrm{~mL}$ of deionised water to the $\mathrm{NaOH}$, precipitating the carbonate with $1 \mathrm{~mL}$ of $2 \mathrm{M} \mathrm{BaCl}_{2}$, and the remaining $\mathrm{NaOH}$ (excess alkali) was back-titrated with $0.05 \mathrm{M} \mathrm{HCl}$ using an automatic titration unit (Anderson 1982).

\section{Statistical analysis}

The experimental design for all incubation experiments was a randomised complete block design with 4 replicates. Statistical analysis 
of inorganic $\mathrm{N}\left(\mathrm{NH}_{4}\right.$ and $\left.\mathrm{NO}_{3}\right)$, leached or extracted at each sample time, was conducted using a one-way ANOVA. Cumulative inorganic $\mathrm{N}$ leached during the 30 weeks of incubation was calculated by summing the inorganic $\mathrm{N}$ leached from each sample interval. Cumulative inorganic $\mathrm{N}$ leached from treatments over time was analysed using repeated measures ANOVA with a Greenhouse-Geisser adjustment of the degrees of freedom (Greenhouse and Geisser 1959).

Each field experiment was a randomised complete block (RCBD) with four replicates (Blocks). Statistical analysis was performed using the statistical package Genstat 5 (Release 4.1, 4th Edn) (Lawes Agricultural Trust 1996). In some cases, a log transformation of the data improved the distribution of residuals. Means were separated using least significant differences (1.s.d.). For uniformity, 1.s.d. values were calculated at $P \leq 0.05$, when main effects or interactions were significant at or less than $5 \%$. The relationships between measured parameters were investigated using single regression analysis (Steel and Torrie 1980).

\section{Results}

\section{Aerobic non-leached soil incubation}

Organic N mineralised from the soil and PPS during the 30 -week incubation varied from $76 \mathrm{mg} / \mathrm{kg}$ in the unamended clay soil (control) to $274 \mathrm{mg} / \mathrm{kg}$ in amended (W2) sandy soil (Fig. 1). Sandy soil mineralised larger amounts of $\mathrm{N}$ than clay soil. From the Stockpiled PPS, almost $50 \%$ of organic N was mineralised in the sandy soil, whereas only $10 \%$ was mineralised in the clay soil (Fig. 1). All of the organic $\mathrm{N}$ from the Wet PPS was mineralised in the sandy soil but much less organic $\mathrm{N}$ was mineralised $(<50 \%)$ in the clay soil (Fig. 1). In the former, there appears to be an apparent priming effect on soil organic $\mathrm{N}$ from the application of the wet PPS.

Cumulative organic $\mathrm{N}$ mineralised during the 30 weeks' incubation from the 2 soils amended and unamended with PPS was successfully described by the following first-order

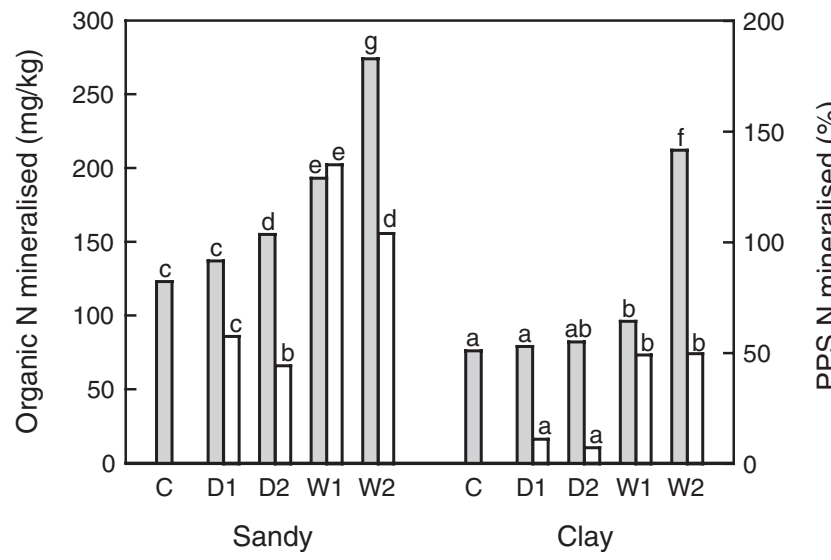

Fig. 1. Organic $\mathrm{N}$ mineralised during 30 weeks of leached incubation (shaded bars) and proportion of organic $\mathrm{N}$ from applied PPS mineralised after discounting for the first week of $\mathrm{N}$ mineralisation due to soil disturbance (open bars) from sandy and clay soils. Within bar shading and soil type, same letters at the top of the bar denote no significant difference at $P=0.05$. exponential equation $\left(R^{2} \geq 0.98\right.$ and low standard error of the estimate, Table 3 ), modified to exclude the initial flush (Beauchamp et al. 1986):

$$
\mathrm{N}_{\mathrm{m}}=\mathrm{N}_{\mathrm{o}}-\left(\mathrm{N}_{\mathrm{o}}-\mathrm{N}_{\mathrm{i}}\right) \exp (-k t)
$$

where $\mathrm{N}_{\mathrm{m}}$ is the organic $\mathrm{N}$ mineralised at time $t$ (week), $\mathrm{N}_{\mathrm{o}}$ is the potentially mineralisable $\mathrm{N}$ or mineralisation potential (Stanford and Smith 1972) at infinite time $(\propto)$, and $\mathrm{N}_{\mathrm{i}}$ is the mineral $\mathrm{N}$ initially present or mineralised in the first week due to soil disturbance. The mineralisation rate constant of organic $\mathrm{N}$ is given by $k$ (/week) in Eqn 1 .

As for the 30-week cumulative $\mathrm{N}$ mineralised, potentially mineralisable $\mathrm{N}$ was higher for the sandy soil $(156 \mathrm{mg} / \mathrm{kg})$ than for the clay soil $(96 \mathrm{mg} / \mathrm{kg})$, although soil total $\mathrm{N}$ in the $0-0.1 \mathrm{~m}$ layer of the sandy soil was lower $(0.043 \%)$ than for the clay soil $(0.080 \%)$. The sandy soil also had higher amounts of net organic $\mathrm{N}$ mineralised from the applied PPS than the clay soil (Table 3). However, mineralisation rate constants, $k$ values, showed little variation between the PPS-amended and unamended soils or across soil types (mean $k$ value $=0.057 /$ week) $($ Table 3$)$. Estimated potentially mineralisable $\mathrm{N}$ values, using the mean $k$ value, were significantly $\left(R^{2}>0.99\right)$ increased by wet PPS application and remained higher in the sandy soil than in the clay soil (Table 3).

The total amount of $\mathrm{CO}_{2}$ evolved was similar for comparable treatments on the two contrasting soils during the 30 weeks of incubation, except for the W2 treatment (Fig. 2). The $\mathrm{W} 2$ treatment evolved more $\mathrm{CO}_{2}$ when applied

Table 3. Mineralisation rate constant ( $k$, per week) and potentially mineralisable $\mathrm{N}\left(\mathrm{N}_{0}, \mathrm{mg} / \mathrm{kg}\right)$ estimated from the 30-week leached incubation of unamended and PPS-amended sandy and clay soils $\mathrm{N}_{\mathrm{m}}=\mathrm{N}_{\mathrm{o}}-\left(\mathrm{N}_{\mathrm{o}}-\mathrm{N}_{\mathrm{i}}\right) \exp (-\mathrm{kt})$, where $\mathrm{N}_{\mathrm{m}}$ is the organic $\mathrm{N}$ mineralised at time $t$ (week), $\mathrm{N}_{\mathrm{o}}$ is the potentially mineralisable $\mathrm{N}$ or mineralisation potential at infinite time $(\propto)$, and $\mathrm{N}_{\mathrm{i}}$ is the mineral $\mathrm{N}$ initially present or mineralised in the first week due to soil disturbance. D1 and D2, Stockpiled PPS applied at 6 and $18 \mathrm{t} /$ ha equivalent; W1 and W2, Wet PPS applied at 17.5 and $52.5 \mathrm{t} / \mathrm{ha}$. Within column, values followed by the same letter are not significantly different at $P=0.05$

\begin{tabular}{lcccccr}
\hline Treatment & $k$ & $\mathrm{~N}_{\mathrm{o}}$ & $R^{2}$ & s.e.e. $^{\mathrm{A}}$ & $\mathrm{N}_{\mathrm{o}}{ }^{\mathrm{B}}$ & PPS N $_{\mathrm{o}}{ }^{\mathrm{C}}$ \\
\hline D1 & 0.044 & 193 & 0.997 & 2.87 & $169 \mathrm{bc}$ & $13 \mathrm{a}$ \\
D2 & 0.044 & 221 & 0.997 & 3.07 & $193 \mathrm{~cd}$ & $37 \mathrm{~b}$ \\
W1 & 0.069 & 237 & 0.986 & 8.05 & $256 \mathrm{~d}$ & $100 \mathrm{~d}$ \\
W2 & 0.076 & 299 & 0.985 & 10.7 & $335 \mathrm{e}$ & $179 \mathrm{f}$ \\
\multicolumn{7}{c}{ Clay soil } \\
D1 & 0.032 & 137 & 0.998 & 1.15 & $98 \mathrm{a}$ & $2 \mathrm{a}$ \\
D2 & 0.032 & 141 & 0.997 & 1.48 & $102 \mathrm{a}$ & $6 \mathrm{a}$ \\
W1 & 0.044 & 174 & 0.997 & 1.95 & $158 \mathrm{~b}$ & $62 \mathrm{c}$ \\
W2 & 0.054 & 250 & 0.996 & 3.17 & $245 \mathrm{~d}$ & $149 \mathrm{e}$ \\
\hline
\end{tabular}

\footnotetext{
${ }^{\mathrm{A}}$ Standard error of estimate.

${ }^{\mathrm{B}} \mathrm{N}_{\mathrm{o}}$ estimated from mean $k$ value $(0.0569 /$ week).

${ }^{\mathrm{C}}$ Net mineralisation potential of PPS applied to soil (control soil value subtracted; 1.s.d. $(P=0.05)=14.7 \mathrm{mg} / \mathrm{kg}$ soil $)$.
} 


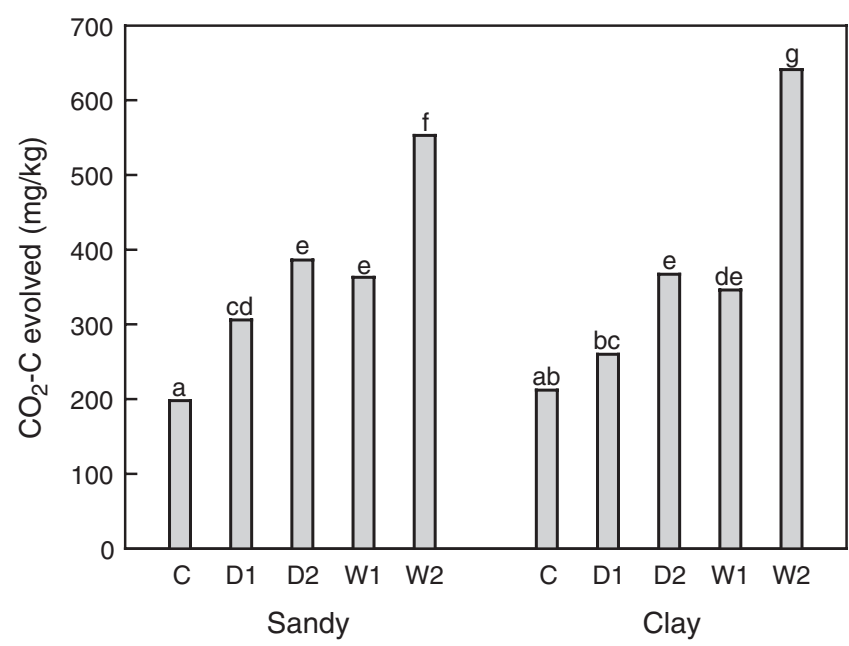

Fig. 2. The relationship between total $\mathrm{CO}_{2}$ evolved during 30 weeks of incubation and the organic $\mathrm{C}$ content of unamended and PPS-amended sandy and clay soils. Within a soil type, same letters at the top of the bar denote no significant difference at $P=0.05$.

to the clay soil than when applied to the sandy soil. Addition of PPS increased the amount of $\mathrm{CO}_{2}$ evolved, except for the $6 \mathrm{t} / \mathrm{ha}$ Stockpiled PPS treatment (D1) on the clay soil. Organic $\mathrm{N}$ mineralised and $\mathrm{CO}_{2}-\mathrm{C}$ evolved during the 30 -week incubation were significantly correlated $\left(R^{2}=0.60\right)$.

\section{Aerobic non-leached incubation}

Application of Wet PPS resulted in a net increase in $\mathrm{NO}_{3}-\mathrm{N}$ extracted following 12 weeks of incubation in both soils (Table 4). As the application rate of Wet PPS increased, the amount of $\mathrm{NO}_{3}-\mathrm{N}$ produced also increased. The proportion of organic N mineralised from the Wet PPS was $17 \%$ for the W2 treatment on the sandy soil and 22\% for the W2 treatment on the clay soil. No net mineralisation of organic $\mathrm{N}$ occurred from the Stockpiled PPS treatments.

The amount of $\mathrm{NO}_{3}$ released during 12 weeks of incubation by non-leached and leached studies was strongly correlated $\left(R^{2}>0.96\right)$ on both soils (Fig. 3). However, net $\mathrm{NO}_{3}$ extracted following 12 weeks of aerobic non-leached incubation was $<60 \%$ of that released during 12 weeks of aerobic leached incubation from both sandy and clay soils (Fig. 3).

\section{Anaerobic (waterlogged) incubation}

Similar to aerobic non-leached incubation, Wet PPS treatments significantly increased anaerobically mineralisable $\mathrm{N}$ whether field-moist or air-dried soil samples were used for incubation (Table 4). However, the amounts of mineralisable $\mathrm{N}$ in air-dried soil were higher than in the fieldmoist soil, and higher in the clay soil than in the sandy soil. The anaerobically mineralisable $\mathrm{N}$ was strongly correlated with $\mathrm{N}$ mineralised during aerobic leached incubation
Table 4. Net change in nitrate- $\mathrm{N}$ under aerobic non-leached incubation ( $\mathrm{Net} \mathrm{NO}_{3}-\mathrm{N}, \mathrm{mg} / \mathrm{kg}$ ) and ammonium-N produced under anaerobic incubation $\left(\mathrm{NH}_{4}-\mathrm{N}, \mathbf{m g} / \mathbf{k g}\right)$ in two PPS-amended soils

D1 and D2, Stockpiled PPS applied at 6 and $18 \mathrm{t} /$ ha equivalent; $\mathrm{W} 1$ and W2, Wet PPS applied at 17.5 and $52.5 \mathrm{t} / \mathrm{ha}$. The sandy soil in the control treatment contained $7.0,4.7$, and $15.1 \mathrm{mg} / \mathrm{kg}$ net amount of $\mathrm{NO}_{3}-\mathrm{N}$, field-moist soil $\mathrm{NH}_{4}-\mathrm{N}$, and air-dried soil $\mathrm{NH}_{4}-\mathrm{N}$, respectively; the corresponding values in the clay soil were 4.7, 7.4, and $31.0 \mathrm{mg} / \mathrm{kg}$. Within a column, values followed by the same letter are not significantly different at $P=0.05$

\begin{tabular}{lccc}
\hline Treatment & $\begin{array}{c}\text { Aerobic non-leached } \\
\text { incubation } \\
\text { Net } \mathrm{NO}_{3}-\mathrm{N}\end{array}$ & $\begin{array}{c}\text { Anaerobic incubation } \\
\text { Field-moist } \\
\mathrm{NH}_{4}-\mathrm{N}\end{array}$ & $\begin{array}{c}\text { Air-dried } \\
\mathrm{NH}_{4}-\mathrm{N}\end{array}$ \\
\hline \multicolumn{4}{c}{ Sandy soil } \\
D1 & $1.3 \mathrm{a}$ & $1.5 \mathrm{a}$ & $0.8 \mathrm{ab}$ \\
D2 & $-1.5 \mathrm{a}$ & $2.3 \mathrm{a}$ & $-0.7 \mathrm{a}$ \\
W1 & $35.8 \mathrm{~b}$ & $5.0 \mathrm{c}$ & $9.1 \mathrm{c}$ \\
W2 & $101.0 \mathrm{c}$ & $11.7 \mathrm{~d}$ & $22.7 \mathrm{e}$ \\
& Clay soil & & \\
D1 & $0.9 \mathrm{a}$ & $1.7 \mathrm{a}$ & $3.4 \mathrm{~b}$ \\
D2 & $-0.3 \mathrm{a}$ & $2.0 \mathrm{a}$ & $1.9 \mathrm{~b}$ \\
W1 & $33.6 \mathrm{~b}$ & $3.3 \mathrm{bc}$ & $10.0 \mathrm{c}$ \\
W2 & $98.3 \mathrm{c}$ & $12.4 \mathrm{~d}$ & $13.8 \mathrm{~d}$ \\
\hline
\end{tabular}

(Fig. 4), but the regression slope of the air-dried soil (0.105) was twice the slope of the field-moist soil (0.05). In contrast, the anaerobically mineralisable $\mathrm{N}$ from field-moist clay soil was better correlated $\left(R^{2}=0.93\right)$ with net $\mathrm{N}$ mineralised during aerobic leached incubation than anaerobically mineralisable $\mathrm{N}$ from air-dried clay soil $\left(R^{2}=0.65\right)$ (Fig. 4). However, the slopes of the 2 relationships were similar $(0.045)$ but the intercepts were significantly different, indicating that air-drying released mineralisable $\mathrm{N}$, possibly from the killed microbial biomass.

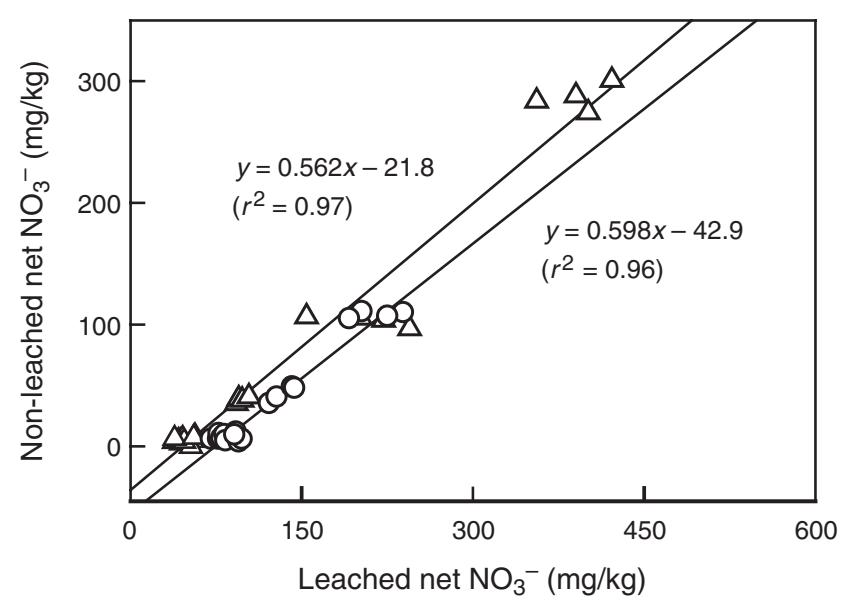

Fig. 3. The relationship between net $\mathrm{NO}_{3}-\mathrm{N}$ extracted during 12 weeks of aerobic non-leached incubation and 12 weeks of aerobic leached incubation from unamended and PPS-amended sandy (O) and clay $(\triangle)$ soils. 


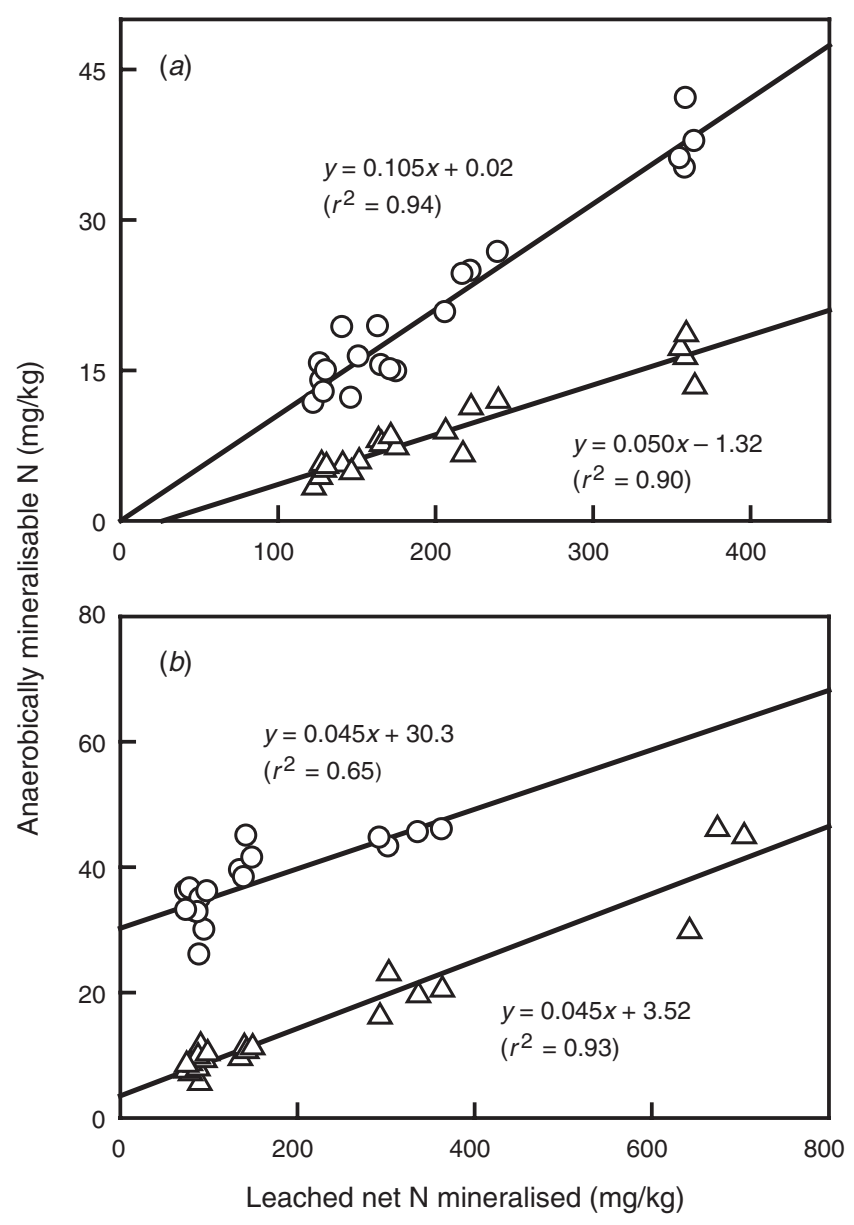

Fig. 4. The relationship between anaerobically mineralisable $\mathrm{N}$ and net $\mathrm{N}$ mineralised during 30 weeks of aerobic leached incubation from unamended and PPS-amended air-dried $(O)$ and field-moist $(\triangle)$ (a) sandy soil and (b) clay soil.

\section{Soil profile nitrate accumulation}

Amounts of $\mathrm{NO}_{3}$ in the sandy soil $(0-1.5 \mathrm{~m})$ after fallowing (December 1997-September 1998) were 52, 47, 58,56 , and $119 \mathrm{~kg} \mathrm{~N} / \mathrm{ha}$ (1.s.d., $P<0.05,31 \mathrm{~kg} \mathrm{~N} / \mathrm{ha}$ ) in the control, D1, D2, W1, and W2 treatments, respectively. The amounts of $\mathrm{NO}_{3}$ in the clay soil profile after fallowing for a similar period in the corresponding treatments were 36 , $68,111,83$, and $127 \mathrm{~kg} \mathrm{~N} / \mathrm{ha}$ (1.s.d., $P<0.05,34 \mathrm{~kg} \mathrm{~N} / \mathrm{ha}$ ). In neither soil, however, was there a significant increase in $\mathrm{NO}_{3}$ in the $1.2-1.5 \mathrm{~m}$ layer (Kliese 2002) after application of PPS. The net change in $\mathrm{NO}_{3}$ content as a proportion of organic $\mathrm{N}$ in the Stockpiled PPS for the D1, D2, and $\mathrm{W} 1$ treatments on the sandy soil was negligible $(-5.3,4.5$, and $4.6 \%$, respectively). On the clay soil, however, $81 \%$ of the organic $\mathrm{N}$ applied in the D1 treatment and $59 \%$ of the organic $\mathrm{N}$ applied in the D2 treatment appeared mineralised. The $25 \%$ of total $\mathrm{N}$ applied in the W2 treatment available on the sandy soil $\left(66 \mathrm{~kg} \mathrm{NO}_{3}{ }^{-}-\mathrm{N} / \mathrm{ha}\right)$ was similar to the amount of mineral $\mathrm{N}$ contained in the applied
Wet PPS ( $\left.81 \mathrm{~kg} \mathrm{NH}_{4}{ }^{+}-\mathrm{N} / \mathrm{ha}\right)$. Similarly, the proportion of $\mathrm{NO}_{3}-\mathrm{N}$ present in the $\mathrm{W} 1$ treatment $(29 \%)$ and the W2 treatment $(19 \%)$ on the clay soil 9 months after application of PPS was similar to the quantity of mineral N contained in the applied Wet PPS, thus emphasising the importance of mineral $\mathrm{N}$ contained in Wet PPS applied directly from the pond.

Value of laboratory tests to estimate $N$ release in PPS-amended soils

Relationships between laboratory estimates of $\mathrm{N}$ mineralisation potential, $\mathrm{NO}_{3}$ released during the 30week incubation (leached), $\mathrm{NO}_{3}-\mathrm{N}$ released during the 12-week incubation (non-leached), and $\mathrm{NH}_{4}-\mathrm{N}$ released during the 7-day anaerobic incubation, and the quantities of $\mathrm{NO}_{3}$ determined in situ after PPS field application, are shown in Fig. 5. For the sandy soil, all laboratory incubations were significantly correlated $\left(R^{2}=0.9-0.95\right)$ with $\mathrm{NO}_{3}$ measured in the field. In contrast, for the clay soil, laboratory incubations were poorly correlated $\left(R^{2}=0.46-0.50\right)$ with $\mathrm{NO}_{3}$ measured in the field, except for anaerobic mineralisable $\mathrm{N}\left(R^{2}=0.59\right)$. Thus, it is possible to improve the predictability of $\mathrm{N}$ uptake by crops from PPS-amended soils by including the immediately available source such as $\mathrm{NO}_{3}$ in the soil and potentially mineralisable $\mathrm{N}$ such as anaerobically mineralisable $\mathrm{N}$, which may become available during the crop growth.

\section{Discussion}

\section{Influence of sludge treatment on $N$ release in soil}

Two differences between stockpiled and wet piggery pond sludges applied in these studies might explain apparent difference in $\mathrm{N}$ release after their application to soil. Firstly, the higher lignin content of stockpiled sludge than of wet sludge, evident from ratios of lignin to $\mathrm{C}, \mathrm{N}$, or organic $\mathrm{N}$, could be one reason for the decreased release of $\mathrm{N}$ after application of stockpiled than after wet application. Secondly, the high content of mineral N, mainly ammonium-N, in wet sludge would have exacerbated this difference in available $\mathrm{N}$ supply after applications of the 2 sludges.

The low proportions of organic $\mathrm{N}$ mineralised from the Stockpiled PPS, applied to the clay soil $(11 \%$ for the D1 treatment and 7\% for the D2 treatment), were similar to the $8 \%$ for composted and $15 \%$ for anaerobically digested sewage sludge applied to a silt loam soil, reported by Parker and Sommers (1983), and to the 13-18\% reported by Zaman et al.(1998) from the incubation of dairy pond sludge with silt loam soil. Similar low proportions of organic $\mathrm{N}$ mineralised on fine textured soils were probably due to these organic materials all being stabilised during storage.

To effectively utilise PPS as an N source for crop production, the rate of $\mathrm{N}$ release by mineralisation must 

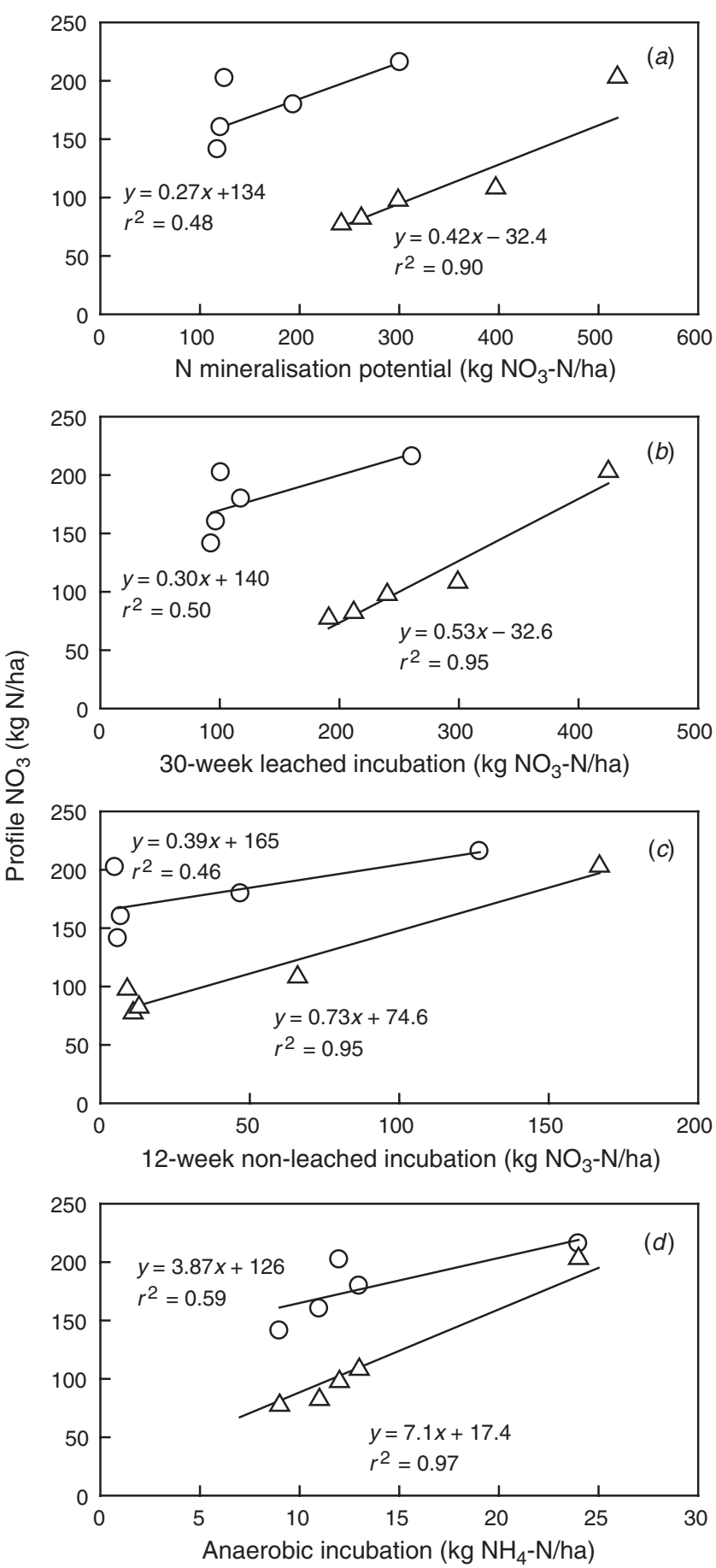

Fig. 5. Relationship between accumulated $\mathrm{NO}_{3}-\mathrm{N}$ in the soil profile and $\mathrm{NO}_{3}-\mathrm{N}$ estimated from $(a) \mathrm{N}$ mineralisation potential, (b) 30-week leached incubation, (c) 12-week non-leached incubation, and $(d) \mathrm{NH}_{4}-\mathrm{N}$ produced during anaerobic incubation in unamended and PPS-amended sandy $(O)$ and clay $(\triangle)$ soils.

be predicted. Thus, it would be beneficial to determine the reasons why the rates of $\mathrm{C}$ and $\mathrm{N}$ mineralisation differ among sludges. According to the total $\mathrm{C} /$ total $\mathrm{N}$ and the total C/organic $\mathrm{N}$ ratios, the 2 forms of PPS should behave similarly when applied to soil (Table 2). Incubation studies showed that the proportion of organic $\mathrm{N}$ from the Wet PPS mineralised more than that from Stockpiled PPS (Tables 3 and 4; Fig. 1). Others have also shown that the $\mathrm{C} / \mathrm{N}$ ratio is not well correlated with decomposition of some substrates and that materials with similar C/N ratios may decompose differently (Gilmour et al. 1985; Levi-Minzi et al. 1990; Fauci and Dick 1994). Therefore, it is considered that the $\mathrm{C} / \mathrm{N}$ ratio as an indicator of organic matter $(\mathrm{OM})$ decomposition is no longer relevant when stabilised materials such as PPS are being considered. However, if the lignin/total N, lignin/organic N (Table 2) and lignin/total $\mathrm{C}$ ratios are considered, then a difference exists between the Wet PPS and Stockpiled PPS. For example, the lignin/organic $\mathrm{N}$ ratio of the Wet PPS was lower (5.9) than of the Stockpiled PPS (19.2). The higher lignin content of the Stockpiled PPS would suggest that its OM would be more stable or recalcitrant than the OM contained in Wet PPS. Hence, land-applied Wet PPS would be expected to be a better source of mineralisable $\mathrm{N}$ for crop use. Moreover, the high content of inorganic $\mathrm{N}$ in Wet PPS, largely as $\mathrm{NH}_{4}$ (1240 mg N/kg on as-collected basis) would further elevate Wet PPS over Stockpiled PPS as a nutrient source for land application.

\section{Influence of soil texture on $N$ release from applied sludge}

As has been previously reported (Castellanos and Pratt 1981; Chae and Tabatabai 1986; Ladd et al. 1992), net N mineralisation was lower in the soil with the higher clay content, due possibly to the combined effect of soil aeration and immobilization, since ammonium fixation appears to be $<5 \%$ of applied $\mathrm{NH}_{4}-\mathrm{N}$ in the clay soils of the region (Black and Waring 1972). All 4 laboratory estimates of $\mathrm{N}$ release after application of the 2 sludges, organic $\mathrm{N}$ mineralised over 30 weeks (Fig. 1), potentially mineralisable N (Table 3 ), and aerobic (12 weeks) and anaerobic ( 7 days) mineralisable $\mathrm{N}$ (Table 4), indicated higher net mineral $\mathrm{N}$ values after application to sandy soil than after application to a clay soil. There may have been a priming effect on soil organic $\mathrm{N}$ in the sandy soil from the application of Wet PPS due to its relatively labile organic $\mathrm{N}$ (and C), whereas in the clay soil these constituents would have been rapidly sorbed, retained, or immobilised by the clay. For example, Sørensen and Jensen (1995) found that net $\mathrm{N}$ immobilisation from cattle slurry increased with increasing clay content. Thus, effect on immobilisation due to contrasting clay content could explain the considerable difference in apparent release of $\mathrm{N}$ from PPS applied to these two soils.

Protection of OM, in particular PPS, in many small pores of the clay soil, as suggested by Hassink et al. (1993), is an unlikely explanation for lower net $\mathrm{N}$ mineralisation than in the sandy soil. Unamended soils displayed similar difference in net $\mathrm{N}$ mineralisation. Furthermore, application of PPS to field-moist soil immediately prior to incubation would 
have given little opportunity for PPS to occupy smaller soil pores.

\section{Comparison of estimates of $N$ mineralisation with those of other studies}

Estimated potentially mineralisable $\mathrm{N}$ for unamended sandy soil was $160.5 \mathrm{mg} \mathrm{N} / \mathrm{kg}$ and for unamended clay soil was $115.6 \mathrm{mg} \mathrm{N} / \mathrm{kg}$ soil. These values were within the range of mean values $(110-270 \mathrm{mg} \mathrm{N} / \mathrm{kg}$ soil), reported for 7 soil orders by Jones et al. (1982). A Waco Black Earth similar to the clay soil used in this study was found by Dalal and Mayer (1987) to have higher potentially mineralisable $\mathrm{N}, 203 \mathrm{mg} \mathrm{N} / \mathrm{kg}$ soil, than the clay used in these studies, $115.6 \mathrm{mgN} / \mathrm{kg}$ soil. This difference was due probably to higher total $\mathrm{N}$ content $(0.14 \%$ v. $0.08 \%)$ and a higher incubation temperature $\left(40^{\circ} \mathrm{C}\right.$ for 30 weeks) used by Dalal and Mayer (1987). Therefore, the value for potentially mineralisable $\mathrm{N}$ determined at $20^{\circ} \mathrm{C}$ in this study at approximately half of the value reported by Dalal and Mayer (1987), would seem comparable.

Similarly, mineralisation rate constants were similar (0.032-0.076/week) (Table 3) to those of other workers who used a long incubation period (30 weeks) and a lower temperature $\left(20^{\circ} \mathrm{C}\right)$ (Chae and Tabatabai 1986; Simard and Ndayegamiye 1993).

Parameter estimates from studies with longer incubation times invariably result in larger potentially mineralisable $\mathrm{N}$ and lower and less variable mineralisation rate constants (Paustian and Bonde 1987; Sierra 1990). The mineralisation rate constants for unamended sandy soil $(0.053 /$ week $)$ and unamended clay soil $(0.04 /$ week $)$ were similar to the mean mineralisation rate constants of Waco Black Vertosols (0.050/week) but lower than of Langlands-Logie and Cecilvale Grey Vertosols $\left(0.075-0.078\right.$ /week) incubated for 30 weeks at $40^{\circ} \mathrm{C}$ by Dalal and Mayer (1987).

\section{Comparison of estimates of $C$ mineralisation with those of other studies}

In contrast to substantial effects on $\mathrm{N}$ mineralisation, soil type had little effect on the total $\mathrm{CO}_{2}$ released during 30 weeks of incubation from unamended or PPS-amended soil. Hassink et al. (1993) also reported no significant effect of soil texture on the percentage of organic $\mathrm{C}$ mineralised, even though $\mathrm{N}$ mineralisation was affected by soil texture as found in our studies. Comparable results have been reported where sewage sludge was applied to a wide range of soils differing in $\mathrm{pH}$, clay, and $\mathrm{OM}$ contents; soil properties were not found to be significant factors in determining the extent of $\mathrm{C}$ mineralisation after sewage sludge incorporation into soil (Gilmour et al. 2003). However, some researchers have reported greater $\mathrm{C}$ stabilisation in soils with higher clay contents (Sørensen and Jensen1995,). When estimating parameters to describe organic $\mathrm{N}$ mineralisation from application of PPS, it is essential to ensure that the effects of initial inorganic $\mathrm{N}$ are excluded.

The low proportion of organic $\mathrm{N}$ from Wet PPS mineralised in aerobic non-leached incubation in comparison with that mineralised in the aerobic leached incubation (Fig. 1), is more than likely due to the closed system of the aerobic non-leached incubation. This resulted in higher $\mathrm{N}$ immobilisation in the non-leached system because $\mathrm{C}$ and $\mathrm{N}$ are not regularly displaced as they were in the aerobic leached incubation (Garau et al. 1986; Hart et al. 1994). However, organic $\mathrm{N}$ mineralised as $\mathrm{NO}_{3}$ was closely correlated (Fig. 3) between the aerobic leached incubation and aerobic nonleached incubation.

\section{Use of laboratory estimates to determine supplementary crop $N$ needs}

Anaerobic incubation was sensitive enough to detect significant differences between mineralisable $\mathrm{N}$ following amendment of sandy and clay soils with PPS. Short-term (7 day) anaerobic incubation resulted in $\mathrm{N}$ release that was well correlated with that derived from a 30-week aerobic incubation, leached regularly. Soil drying prior to incubation increased $\mathrm{N}$ release from both soils as has been previously observed (Westerman et al. 1988). Since soil drying had a somewhat different influence on $\mathrm{N}$ released anaerobically (Fig. $4 a, b$ ) when using this test across different soils fieldmoist soil would be preferable. Short-term ( 7 day) anaerobic incubation also has been shown to be a useful comparative measure of $\mathrm{N}$ release for soil amended with plant residues by Hossain et al. (1996), who investigated the effects of leguminous ley pastures on $\mathrm{N}$ release in soils of south-eastern Queensland (Warra).

Net $\mathrm{N}$ supply as $\mathrm{NO}_{3}-\mathrm{N} /$ ha produced from PPS application can be estimated from the relationship between fieldmeasured $\mathrm{NO}_{3}$ and laboratory measures of mineral $\mathrm{N}$ released from PPS-amended and unamended soils (Table 5). For example, additional $20 \mathrm{~kg} \mathrm{NO}_{3}-\mathrm{N} / \mathrm{ha}$ can be supplied by the application of $17.5 \mathrm{t} / \mathrm{ha}$ of the wet PPS in both soils. This can be rapidly assessed from the 7-day anaerobic incubation.

Table 5. Net $\mathrm{N}$ supply (kg/ha soil $\left.\mathrm{NO}_{3}-\mathrm{N}\right)$ from Wet PPS application estimated from the relationship between field $\mathrm{NO}_{3}$ and the four laboratory measures of mineral $N$ release from PPS-amended and unamended soils in Fig. 5 $\mathrm{W} 1$ and W2, Wet PPS applied at 17.5 and $52.5 \mathrm{t} / \mathrm{ha}$

\begin{tabular}{lcccc}
\hline Treatment & $\mathrm{N}_{\mathrm{o}}$ & $\begin{array}{c}30 \text { weeks } \\
\text { leached }\end{array}$ & $\begin{array}{c}\text { 12 weeks } \\
\text { aerobic }\end{array}$ & $\begin{array}{c}7 \text { days } \\
\text { anaerobic }\end{array}$ \\
\hline W1 & 20.8 & 29.8 & 17 & 19.3 \\
W2 & 37.5 & 53.5 & 43 & 45.3 \\
& \multicolumn{5}{c}{ Sandy } \\
W1 & 24.4 & 32.8 & 35.9 & 23.5 \\
W2 & 56.3 & 79 & 82.6 & 88.1 \\
\hline
\end{tabular}




\section{Conclusions}

Differences in susceptibility to decomposition of Wet PPS and Stockpiled PPS are evident from both the aerobic non-leached and anaerobic incubation methods, with Wet PPS being more susceptible to decomposition. Results from both incubation methods were well correlated with the results from aerobic leached incubation, except for the net $\mathrm{N}$ mineralised during aerobic non-leached incubation. Since anaerobic incubation is also better correlated with field $\mathrm{NO}_{3}$, anaerobic incubation would, therefore, be suitable as a rapid practical test to detect differences in potentially mineralisable $\mathrm{N}$ following additions of PPS on a field scale. Anaerobic mineralisable $\mathrm{N}$ was determined on field soil samples where Stockpiled and Wet PPS were applied, and along with $\mathrm{NO}_{3}$, was correlated with crop $\mathrm{N}$ uptake and crop yield. The results are presented in the subsequent paper. In conclusion, wet PPS provides a readily available mineral $\mathrm{N}$ source for crops.

\section{Acknowledgments}

We thank the Pig Research and Development Corporation for financial support, J. Standley, K. Spann, and J. Hagedorn for technical support, J. Cooper and S. Rowlings for field assistance, and K. Bell for statistical advice. We thank the two anonymous reviewers for their excellent suggestions.

\section{References}

Anderson JPE (1982) Soil respiration. In 'Methods of soil analysis, Part 2, Chemical and microbiological properties'. Agronomy 9, 2nd edn (Eds AL Page, RH Miller, DR Keeney) pp. 831-871. (American Society of Agronomy, Soil Science Society of America: Madison, WI)

Beauchamp EG, Reynolds WD, Brasche-Villeneuve D, Kirby K (1986) Nitrogen mineralization kinetics with different soil pretreatments and cropping histories. Soil Science Society of America Journal 50, 1478-1483.

Bernal MP, Roig A (1993) Nitrogen transformations in calcareous soils amended with pig slurry under aerobic incubation. Journal of Agricultural Science, Cambridge 120, 89-97.

Best EK (1976) An automated method for determining nitrate nitrogen in soil extracts. Queensland Journal of Agricultural and Animal Sciences 33, 161-166.

Black AS, Waring SA (1972) Ammonium fixation and availability in some cereal producing soils in Queensland. Australian Journal of Soil Research 10, 197-207.

Bremner JM (1965) Inorganic forms of nitrogen. In 'Methods of soil analysis'. Part 2.' Agronomy 9. (Ed. CA Black) pp. 1179-1237. (American Society of Agronomy: Madison, WI)

Bundy LG, Meisinger JJ (1994) Nitrogen availability indices. In 'Methods of soil analysis, Part 2. Microbiological and biochemical properties'. (Eds RW Weaver, S Angle, P Bottomley, D Bezdicek, S Smith, A Tabatabai, A Wollum) pp. 951-984. (Soil Science Society of America: Madison, WI)

Cameron KC, Rate AW, Carey PL, Smith NP (1995) Fate of nitrogen in pig effluent applied to a shallow stony pasture soil. New Zealand Journal of Agricultural Research 38, 533-542.
Cameron KC, Rate AW, Noonan MJ, Moore S, Smith NP, Kerr LE (1996) Lysimeter study of the fate of nutrients following subsurface injection and surface application of dairy pond sludge to pasture. Agriculture Ecosystems and Environment 58, 187-197. doi: 10.1016/0167-8809(96)01029-8

Campbell CA, Myers RJK, Weier KL (1981) Potentially mineralizable nitrogen, decomposition rates and their relationship to temperature for five Queensland soils. Australian Journal of Soil Research 19, 323-332.

Carey PL, Rate AW, Cameron KC (1997) Fate of nitrogen in pig slurry applied to a New Zealand pasture soil. Australian Journal of Soil Research 35, 941-959. doi: 10.1071/S96088

Castellanos JZ, Pratt PF (1981) Mineralization of manure nitrogen correlation with laboratory indexes. Soil Science Society of America Journal 45, 354-357.

Chae YM, Tabatabai MA (1986) Mineralization of nitrogen in soils amended with organic wastes. Journal of Environmental Quality 15, 193-198.

Clewett JF, Smith PG, Partridge IJ, George DA, Peacock A (1999) 'Australian Rainman Version 3: an integrated software package of rainfall information for better management.' (Q198071 Department of Primary Industries: Queensland)

Crooke WM, Simpson WE (1971) Determination of ammonium in Kjeldahl digests of crops by an automated procedure. Journal of the Science of Food and Agriculture 22, 9-10.

Dalal RC, Mayer RJ (1987) Long-term trends in fertility of soils under continuous cultivation and cereal cropping in southern Queensland. VII. Dynamics of nitrogen mineralization potentials and microbial biomass. Australian Journal of Soil Research 25, 461-472.

Day PR (1965) Particle fractionation and particle size analysis. In 'Methods of soil analysis. Part 1'. Agronomy 9. (Ed. CA Black) pp. 545-567. (American Society of Agronomy: Madison, WI)

Edwards JP, Bremner JM (1965) Dispersion of mineral colloids in soil using cation exchange resins. Nature 205, 208-209.

Estavillo JM, Rodriguez M, Lacuesta M, Gonzalez-Murua C (1997) Effects of cattle slurry and mineral $\mathrm{N}$ fertilizer applications on various components of nitrogen balance of mown grassland. Plant and Soil 188, 49-58. doi: 10.1023/A:1004248228162

Fauci MF, Dick RP (1994) Plant response to organic amendments and decreasing inorganic nitrogen rates in soils from a longterm experiment. Soil Science Society of America Journal 58, 134-138.

Garau MA, Felipo MT, Ruiz De Villa MC (1986) Nitrogen mineralization of sewage sludges in soils. Journal of Environmental Quality 15, 225-228.

Gilmour JT, Clark MD, Sigua GC (1985) Estimating net nitrogen mineralization from carbon dioxide evolution. Soil Science Society of America Journal 49, 1398-1402.

Gilmour JT, Cogger CG, Jacobs LW, Evanylo GK, Sullivan DM (2003) Decomposition and plant available nitrogen in biosolids: laboratory studies, field studies, and computer simulation. Journal of Environmental Quality 32, 1498-1507.

Greenhouse SW, Geisser S (1959) On methods in the analysis of profile data. Psychometrika 24, 95-112.

Hart SC, Stark JM, Davidson EA, Firestone MK (1994) Nitrogen mineralization, immobilization and nitrification. In 'Methods of soil analysis, Part 2. Microbiological and biochemical properties'. (Eds RW Weaver, S Angle, P Bottomley, D Bezdicek, S Smith, A Tabatabai, A Wollum) pp. 985-1018. (Soil Science Society of America: Madison, WI)

Hassink J, Bouwman LA, Zwart KB, Bloem J, Brussaard L (1993) Relationships between soil texture, physical protection of organic matter, soil biota, and $\mathrm{C}$ and $\mathrm{N}$ mineralisation in grassland soils. Geoderma 57, 105-128. doi: 10.1016/0016-7061(93)90150-J 
Hossain SA, Strong WM, Waring SA, Dalal RC, Weston EJ (1996) Comparison of legume-based cropping systems at Warra, Queensland. II. Mineral nitrogen accumulation and availability to the subsequent wheat crop. Australian Journal of Soil Research 34, 289-297.

Isbell RF (1996) 'The Australian soil classification.' (CSIRO Publishing: Melbourne, Vic.)

Jones CA, Ratliff LF, Dyke PT (1982) Estimation of potentially mineralizable soil nitrogen from chemical and taxonomic criteria. Communications in Soil Science and Plant Analysis 13, 75-86.

Keeney DR (1982) Nitrogen-availability indices. In 'Methods of soil analysis, Part 2, Chemical and microbiological properties'. 2nd edn (Ed. AL Page) pp. 711-733. (American Society of Agronomy, Soil Science Society of America: Madison, WI)

Kliese YJ (2002) Nitrogen dynamics following the application of piggery pond sludge to cropping land in subtropical Australia. $\mathrm{PhD}$ thesis, University of Queensland, Brisbane, Australia.

Ladd JN, Jocteur Monrozier L, Amato M (1992) Carbon turnover and nitrogen transformations in an Alfilsol and a Vertisol amended with $\left(\mathrm{U}^{-14} \mathrm{C}\right)$ glucose and ${ }^{15} \mathrm{~N}$ ammonium sulfate. Soil Biology and Biochemistry 24, 359-371. doi: 10.1016/00380717(92)90196-5

Lawes Agricultural Trust (1996) 'Genstat Version 5, Release 4.1.' (ICAR: Rothamsted, UK)

Levi-Minzi R, Riffaldi R, Saviozzi A (1990) Carbon mineralization in soil amended with different organic materials. Agriculture Ecosystems and Environment 31, 325-335. doi: 10.1016/01678809(90)90231-2

Ndayegamiye A, Côté D (1989) Effect of long-term pig slurry and solid cattle manure application on soil chemical and biological properties. Canadian Journal of Soil Science 69, 39-47.

Parker CF, Sommers LE (1983) Mineralization of nitrogen in sewage sludges. Journal of Environmental Quality 12, 150-156.

Paul JW, Beauchamp EG (1994) Short-term nitrogen dynamics in soil amended with fresh and composted cattle manures. Canadian Journal of Soil Science 74, 147-155.

Paul JW, Beauchamp EG (1995) Availability of manure slurry ammonium for corn using ${ }^{15} \mathrm{~N}$-labelled $\left(\mathrm{NH}_{4}\right)_{2} \mathrm{SO}_{4}$. Canadian Journal of Soil Science 75, 35-42.

Paustian K, Bonde TA (1987) Interpreting incubation data on nitrogen mineralization from organic matter. International Association of Ecology Bulletin 15, 101-112.

Rate AW, Cameron KC (1992) Nutrient mineralisation from soil amended with pig slurry: an incubation study. In 'The use of wastes and byproducts as fertilizers and soil amendments for pastures and crops'. (Eds PEH Gregg, LD Currie, P Bottomley, D Bezdicek, S Smith, A Tabatabai, A Wollum) pp. 261-269. (Fertilizer and Lime Research Centre: Palmerston North, New Zealand)

Rayment GE, Higginson FR (1992) 'Australian laboratory handbook of soil and water chemical methods.' (Inkata Press: Melbourne, Vic.)
Rees RM, Yan L, Ferguson M (1993) The release and plant uptake of nitrogen from some plant and animal manures. Biology and Fertility of Soils 15, 285-293. doi: 10.1007/BF00337214

Rochette P, Angers DA, Côté D (2000) Soil carbon and nitrogen dynamics following application of pig slurry for the $19^{\text {th }}$ consecutive year: II. Nitrous oxide fluxes and mineral nitrogen. Soil Science Society of America Journal 64, 1396-1403.

Serna MD, Pomares F (1991) Comparison of biological and chemical methods to predict nitrogen mineralization in animal wastes. Biology and Fertility of Soils 12, 89-94. doi: 10.1007/BF00341481

Sierra J (1990) Analysis of soil nitrogen mineralization as estimated by exponential models. Soil Biology \& Biochemistry 22, 1151-1153. doi: 10.1016/0038-0717(90)90042-X

Simard RR, Ndayegamiye AN (1993) Nitrogen-mineralization potential of meadow soils. Canadian Journal of Soil Science 73, 27-38.

Sims JR, Haby VA (1971) Simplified colorimetric determination of soil organic matter. Soil Science 122, 137-141.

Sørensen P, Jensen ES (1995) Mineralization-immobilization and plant uptake of nitrogen as influenced by the spatial-distribution of cattle slurry in soils of different texture. Plant and Soil 173, 283-291. doi: $10.1007 / \mathrm{BF} 00011466$

Stanford G, Smith SJ (1972) Nitrogen mineralization potentials of soils. Soil Science Society of America Proceedings 36, 465-472.

Steel RGD, Torrie JH (1980) 'Principles and procedures of statistics. A biometric approach.' 2nd edn (McGraw-Hill: Toronto, Canada)

USDA (1975) 'Soil taxonomy.' (United States Department of Agriculture: Washington DC)

Walkley A, Black IA (1934) An examination of the Degtjareff method for determining soil organic matter, and a proposed modification of the chromic acid titration method. Soil Science 37, 29-38.

Westerman PW, King LD, Burns JC, Cummings GA, Overcash MR (1987) Swine manure and lagoon effluent applied to a temperate forage mixture: II. Rainfall runoff and soil chemical properties. Journal of Environmental Quality 16, 106-112.

Westerman PW, Safley LW Jr, Barker JC (1988) Available nitrogen in broiler and turkey litter. Transactions of the American Society of Agricultural Engineers 31, 1070-1075.

Yang XM, Drury CF, Reynolds WD, Tan CS (2004) Nitrogen mineralisation and uptake by ryegrass in a clay loam soil amended with composts or liquid pig manure. Canadian Journal of Soil Science 84, 11-17.

Zaman M, Cameron KC, Di HJ, Noonan MJ (1998) Nitrogen mineralisation rates from soil amended with dairy pond sludge. Australian Journal of Soil Research 36, 217-230. doi: $10.1071 / \mathrm{S} 97048$

Zebarth BJ, Paul JW, Schmidt O, McDougall R (1996) Influence of the time and rate of liquid-manure application on yield and nitrogen utilization of silage corn in south coastal British Columbia. Canadian Journal of Soil Science 76, 153-164.

Manuscript received 18 August 2004, accepted 17 December 2004 